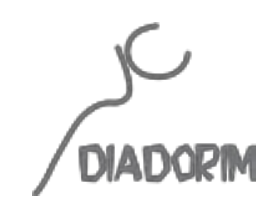

\title{
NATUREZAS-MORTAS \\ DE FIAMA HASSE PAIS BRANDÃO ${ }^{1}$
}

\author{
Mônica Genelhu Fagundes ${ }^{2}$
}

\section{RESUMO}

A poesia de Fiama Hasse Pais Brandão revela um curioso interesse pela pintura de naturezamorta. A expressão é citada em alguns de seus poemas, e outros tantos dialogam com esse gênero pictórico caracterizado pela representação de objetos inanimados, em que a figura humana é, o mais das vezes, elidida. Neste ensaio, buscamos investigar como a poesia de Fiama se apropria da arte da natureza-morta e a ressignifica, valendo-se dela como forma de apreender e transformar o real e sua relação com o sujeito; e, igualmente, como forma de pensar o próprio fazer poético.

PALAVRAS-CHAVE: Fiama Hasse Pais Brandão; Natureza morta; Relações interartes.

\begin{abstract}
The poetry of Fiama Hasse Pais Brandão reveals a curious interest in still-life painting. The expression is mentioned in some of her poems, and many others dialogue with this pictorial genre characterized by the representation of inanimate objects, in which the human figure is,

1 Versões deste trabalho foram apresentadas no Colóquio "A menina que se chamava chama" - um Dia para a poesia de Fiama, na Faculdade de Letras da UFRJ, em 26 de setembro de 2017, e na Jornada "eu, o inconcreto morto", no Instituto de Letras da UFF, em 14 de maio de 2018. Faço o registro como forma de agradecimento aos organizadores e ao público presente, pela oportunidade de desenvolver e discutir a minha leitura.

2 Professora de Literatura Portuguesa na Universidade Federal do Rio de Janeiro. E-mail: monicafagundes@, gmail.com
\end{abstract}

Recebido em: 16/06/2018

Aceito em: 16/08/2018

(cc) BY-NC

A revista Diadorim utiliza uma Licença Creative Commons - Atribuição-NãoComercial 4.0 Internacional (CC-BY-NC).

Diadorim, Rio de Janeiro, vol. 20, n. 1, p, 22-36, jan-jun. 2018. 
most of the time, elided. In this paper, we seek to investigate how Fiama's poetry appropriates and redefines the art of still life, using it as a way of apprehending and transforming reality and its relationship with the self; and also as a way of reflecting about the making of poetry itself.

KEYWORDS: Fiama Hasse Pais Brandão; Still-life painting; Interart relations.

Tudo se fundamenta

Na existência das coisas. Um pomo do tamanho da abóbada celeste.

Fiama Hasse Pais Brandão, Área branca / 34

Em sua definição mais simples, a natureza-morta é uma representação de objetos inanimados. Flores e frutos, pães, doces, conchas e toda sorte de utensílios domésticos - jarros, taças, copos, pratos, facas, pintados com minúcia de detalhes e próximos ao observador, como que ao alcance de sua mão, aparecem dispostos sobre uma superfície e diante de um fundo neutros, que os dão a ver com o máximo de ilusão realista, como se estivessem de fato ali. A História natural, de Plínio o Velho, faz supostamente a primeira alusão a este gênero pictórico muito antigo, narrando a anedota de um desafio entre dois pintores, Zêuxis e Parrásio, que disputavam qual seria o mais virtuoso na imitação da natureza. Zêuxis pintou um cesto com uvas. Eram tão perfeitas que algumas aves, enganadas, vieram tentar bicá-las. O pintor foi, porém, derrotado pelo concorrente. Quando Parrásio apresentou seu próprio quadro, Zêuxis fez menção de puxar a cortina que parecia cobri-lo, apenas para descobrir que a cortina era a pintura. Se Zêuxis fora capaz de enganar animais, Parrásio o superou ao confundir um outro homem, e mais: um pintor (CHERRY, 2010, p. 13).

Talvez em memória dessa história, muitos pintores de naturezas-mortas tenham incluído insetos e outros pequenos animais em seus quadros, e efeitos de trompe-l'oeil, como o sutil enrugado da toalha e a tulipa prestes a cair da tela de Baltasar van der Ast (fig. 1).

FIGURA 1. Balthasar van der Ast. "Natureza-morta com flores e frutas". Óleo sobre tela, 1620.

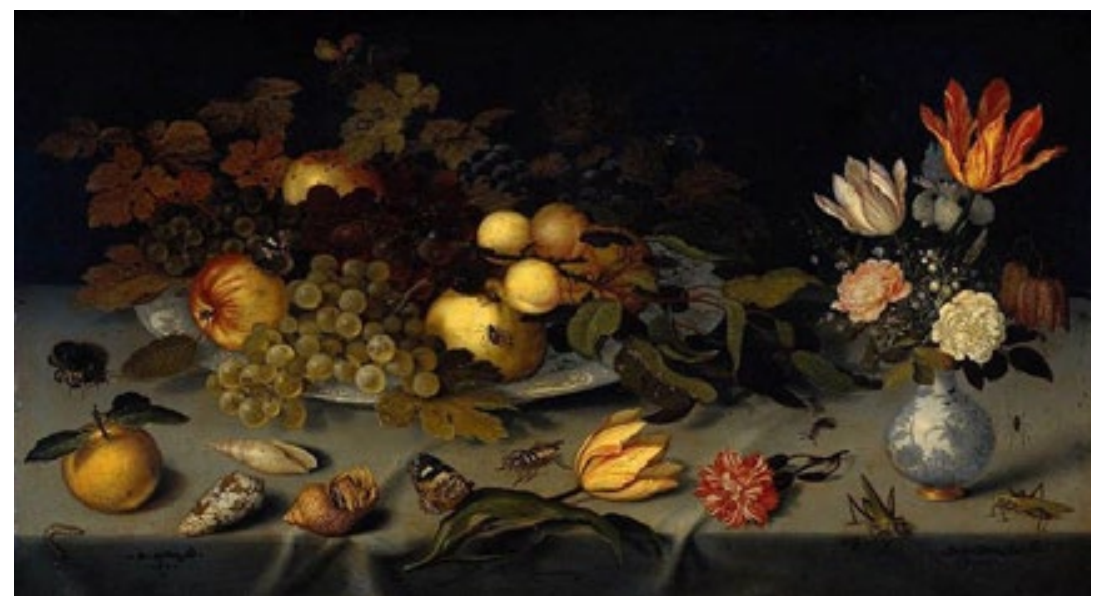


A presença dos insetos - agora também pintados - poderia contribuir para a ilusão mimética da imagem, sugerindo um aspecto que a pintura, por mais tecnicamente perfeita que fosse, não seria capaz de restituir: a fragrância das frutas e das flores, que os teria atraído. Por outro lado, pode sugerir - e esta é a leitura de muitos estudiosos do gênero - a deterioração iminente, ou já em curso, dos elementos naturais, segundo o muito barroco topos do carpe diem: apelo ao presente, alerta para a efemeridade e a finitude de todas as coisas, que se anunciam mesmo no ápice de sua beleza e de sua vitalidade. Não começam a surgir pontos escuros nas maçãs, não parecem estar já secas as folhas das uvas? Em outros quadros desse período, particularmente nomeados Vanitas, são figurados objetos que proclamam em clave mais decisivamente alegórica a passagem do tempo e a consciência da morte que virá: relógios, velas consumidas, retratos e - os mais eloquentes - crânios. Memento mori, é o que anunciam: lembre-se que vai morrer. E, no entanto, mesmo com esse pendor alegórico, sua mensagem está ligada ao que se vê, calcada naquilo que se oferece aos olhos. Como sugere Mark Doty: essas pinturas "sugerem que o conhecimento é visível, que pode ser visto no mundo cotidiano. Elas pensam, por assim dizer, por meio de coisas" (DOTY, 2001, p. 7. Tradução minha).

Para Svetlana Alpers, esse primado das coisas (e de coisas muito prosaicas e familiares) estaria ligado às circunstâncias em que a natureza-morta ressurgiu como uma das grandes expressões da pintura holandesa do século XVII. Um contexto em que, por um lado, o ver assumia papel preponderante na apreensão do real e no desenvolvimento do saber. Com a difusão de novos instrumentos ópticos, com suas lentes que proporcionavam acesso ao muito pequeno (o microscópio) e ao muito distante (o telescópio), iam-se revelando novos mundos e impunha-se o desejo de capturá-los em imagens, criando-se uma "cultura especificamente visual, em oposição a uma cultura textual", cuja ênfase estava em ver e representar, não em ler e interpretar (ALPERS, 1984, p. XXIV). Por outro lado, aproximar-se desses novos mundos recém-descobertos significava trazê-los para o ambiente familiar, íntimo: uma nova imagem do mundo ia tomando forma em interiores domésticos, fosse nos mapas que adornavam paredes, como nas salas pintadas por Vermeer, fosse em naturezas-mortas que permitiam ver uma variedade de elementos em impressionante detalhe miniatural.

Pensar por meio das coisas, do concreto, do tangível, é o que mais aproximaria o poeta do pintor de naturezas-mortas. Num dos muitos poemas em que cria uma natureza-morta verbal, Fiama diz, sobre as dálias que vai colher para um arranjo: "Pensei que são flores comuns, / meias esferas de seca matéria, que atrai / como toda a matéria, abelhas e poetas." (BRANDÃO, 2006, p. 547). Mark Doty vai justificar esse apego ao concreto:

Pensar por meio das coisas, este é o trabalho do pintor de naturezas-mortas - e o do poeta. Ambos tipos de artista que requerem um vocabulário tangível, um léxico mundano. Uma linguagem de ideias é, em si mesma, uma linguagem fantasma, a que falta a substância das coisas do mundo, esses repositórios de sentimento e experiência, memória e tempo. Somos ensinados pelos objetos que falam a nós, essas presenças materiais. (DOTY, 2001, p. 9-10. Tradução minha.)

Diadorim, Rio de Janeiro, vol. 20, n. 1, p, 22-36, jan-jun. 2018. 
Não é precisamente isto o que enuncia Fiama nos versos que nos servem de epígrafe? Um voto de confiança "na existência das coisas", a descoberta de que num pomo se oferece - acessível, mensurável - a abóbada celeste. A nos lembrar as telas do espanhol Juan Sánchez Cotán (fig. 2), em que a música das esferas se revela no interior de uma despensa, com marmelos e repolhos, melões e pepinos a servirem de suporte para teorias geométricas: logaritmo a cumprir-se logo antes do jantar. ${ }^{3}$

FIGURA 2. Juan Sánchez Cotán. "Marmelo, repolho, melão e pepino”. Óleo sobre tela, 1602.

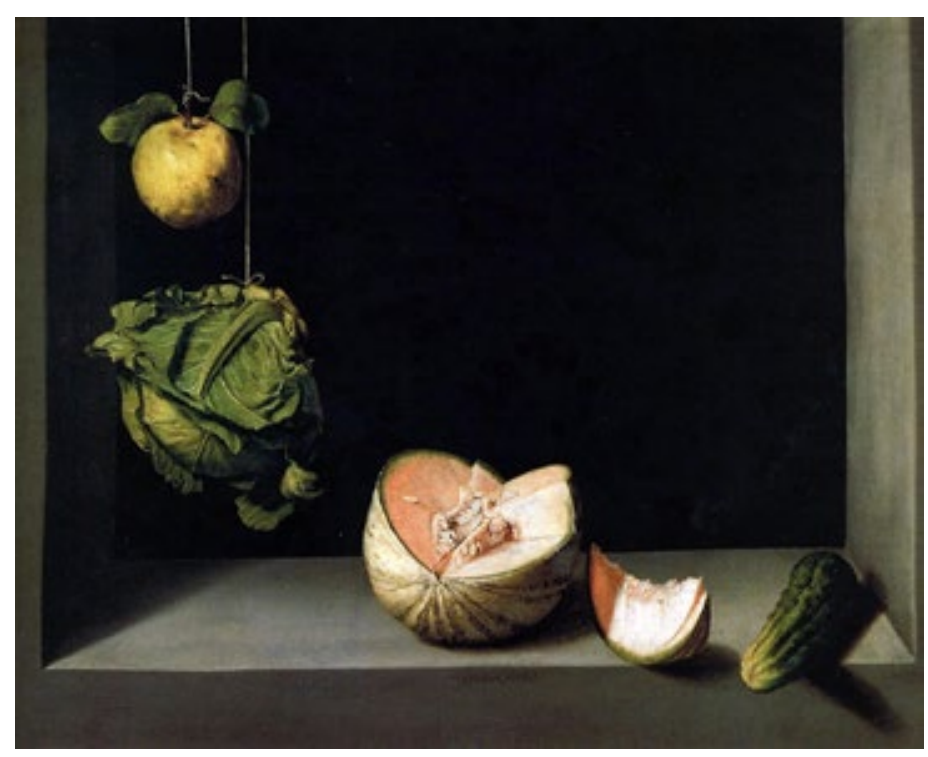

O mundo, o universo se dão a conhecer nos objetos simples representados nessas telas, que, segundo Svetlana Alpers, se concebem e se veem menos como uma janela aberta para o mundo, no sentido albertiano tão difundido, do que como um espelho ou um mapa (ALPERS, 1984, p. XXV). É segundo este regime visual, no qual está implicado um modo peculiar de conhecimento, que o poema "Pão" considera este elemento cotidiano uma forma, uma imagem, uma composição cromática que se revela representação do mundo e artifício para entendê-lo, modo de acesso a ele, reduzido à escala humana, doméstica, pessoal.

Pão

A branca flor do pão lêvedo todas as manhãs se abria sobre a mesa. Era a razão do meu viver nesse tempo na pátria galega, que me dava assim a sua essência. Porque a harmonia do largo mar calmo contra a costa alcantilada ou a rasa ria híbrida e o terreno interior dos verdes brumosos - que de o serem são puros brancos é a mesma suave união de duas faces da escura côdea e do miolo alvo. (BRANDÃO, 2006, p. 529)

3 Sobre o princípio matemático das composições de Juan Sánchez Cotán, ver BRYSON, 2012, p. 66-70. 
O pão ensina a essência da "pátria galega"; contém, mapeados, o seu relevo, o seu litoral, a sua geografia incerta e contrastante. O muito extenso, o estranho, o misterioso se traduzem nessa concretude de coisa cotidiana que se torna "razão do meu viver". "Razão" que possivelmente devemos interpretar aqui menos como motivo, causa, do que como capacidade de pensamento e possibilidade de compreensão, ou mesmo, segundo a perspectiva matemática, como relação entre o sujeito e as suas circunstâncias: "meu viver" : "nesse tempo / na pátria galega", fórmula de conformação de uma subjetividade - também "suave união de duas faces", interior e exterior, miolo e côdea. Espelho, mapa, a aparição do pão todas as manhãs sobre a mesa - do café, da escrita - oferecem ao eu uma imagem do mundo e de si mesmo, a se imiscuírem uma na outra, se considerarmos, numa segunda leitura, que a pátria galega dava - não revelava, mas cedia - ao eu a sua essência. A natureza-morta se vai convertendo em Bildungsroman.

Aprender a pensar por meio das coisas é um processo, uma educação, como Fiama confessa em "Rosas, rosas e lírios", e conduz a um saber que não se limita a desvendar a objetividade do real, mas concerne ao sujeito e à sua condição humana:

Em quantos séculos eu não vi: as rosas e outros seres (a cor sulfúrica) nem vi as naturezas mortas - se o mundo é a figura delas.

Nem tinha antigamente (dia imaturo) este saber: porquanto seja enorme o mesmo mundo, espaços inúmeros, o tacto insaciável, suguem a cada hora os lírios o seu líquido, e os animais (idênticos, outrora) se apascentam em erva rasa (a eterna qualidade desse gado, caprino, é a de ser

isso é fugaz. Percurso para o rebanho ou outra coisa: a finitude.

[parco),

Porém, pensar que a rosa apazigua:

diria que era rosa, una, e que era a espécie.

(BRANDÃO, 2006, p. 113)

Cumprido o aprendizado, este aprendizado fundado no ver, num passar a ver, as naturezas mortas já não se concebem como mera representação do mundo. A relação mimética e a hierarquia nela implicada se invertem: "o mundo é a figura delas". Como mais claramente diz Fiama no "Canto da chávena de chá":

É assim que muitas vezes o chá evoca:

a minha mão de pedra, tarde serena,

olhar dos melros, som leve da bica.

A Natureza copia esta pintura

do fim da tarde que para mim pintei, retribui-me os poemas que eu lhe fiz

de novo dando-me os meus versos ao vivo.

$[\ldots]$

a Natureza dá-me o que lhe dei.

(BRANDÃO, 2006, p. 572)

Numa aproximação a Dante e sua interpretação figural: as naturezas-mortas são a con- 
sumação de um sentido de que o mundo é figura; nelas se completa, se revela, se compreende e perdura todo o saber parcial e precariamente manifestado pelas circunstâncias, pela história, pela individualidade. A enormidade do mundo, a sua variedade, a insaciabilidade da vida, tudo se vai resumindo em lírios que sugam seu líquido e em rebanhos que se apascentam: emblemas da fugacidade, da finitude (primeiro movimento), mas também dotados de "eterna qualidade": sempre os mesmos lírios, sempre os mesmos parcos rebanhos, "idênticos, outrora". Sentidos que finalmente vêm consumar-se numa rosa que é una e toda a espécie, e que, sem obliterar a consciência da passagem do tempo e da morte, apazigua o seu drama numa permanência de repetição, que confina com representação.

Muito comuns, as naturezas-mortas que exibem arranjos de flores representadas com minúcias de realismo guardam um segredo: criam buquês imaginários (fig. 3). Seja pela diferença de tamanho das corolas ou pela altura discrepante das hastes, seja pela época do ano ou pelo lugar do mundo em que florescem, seria impossível reunir essa flores naqueles harmoniosos buquês (BRYSON, 2012, p. 104-105)4. Se perdem no critério de fidelidade ao real, essas pinturas se superam, porém, como consumação: apreendem o mundo em sua multiplicidade, fazem convergir tempos e espaços distintos, criam uma imagem da realidade concentrada, para além de toda limitação. E mais: são uma vitória sobre a natureza e suas constrições.

FIGURA 3. Ambrosius Boschaert o Velho. "Buquê de flores em um nicho". Óleo sobre tela, 1616.

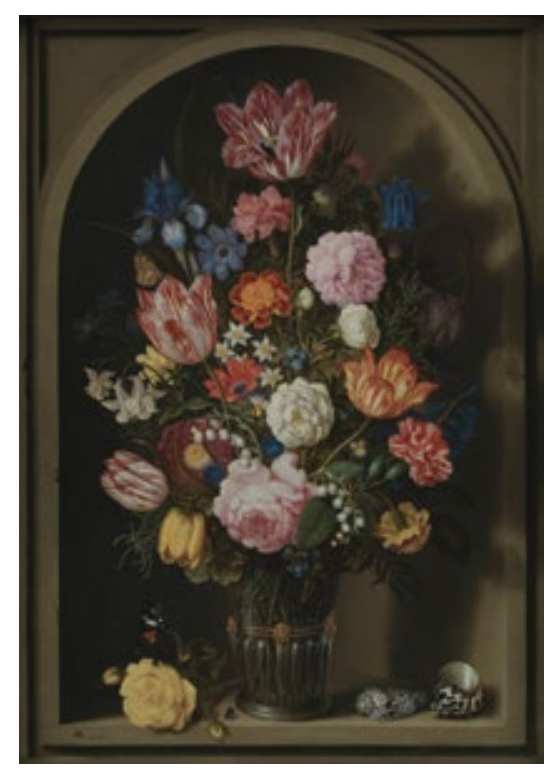

Cada uma dessas flores pintadas, recuperadas de muitas estações em que floresceram, pela técnica de um pintor que as apreendeu, não está sujeita à fugacidade e à finitude, pelo menos não à maneira das flores empíricas. E talvez possa mesmo contaminar com a sua "imortalidade" todas as outras da sua espécie, como Fiama desconfia num poema cujos últimos versos já mencionamos, mas que valerá a pena retomar:

4 Algo semelhante se passa com as conchas, muitas vezes apresentadas em coleções que reúnem espécies recolhidas em diferentes mares, em diferentes pontos do globo, metonimicamente unindo as águas do mundo sobre uma mesa. 
Das flores, prefiro dálias

Talvez as dálias

que mais vezes coloquei em jarras, quando cada ano voltavam, tenham sido por isso

flores menos fugazes. Olharam-me, quando as vi de relance

prontas para a colheita deste ano

e para ornamentarem agora

o meu coração que as bebe, sepultura que as devora.

Pensei que são flores comuns, meias-esferas de seca matéria, que atrai como toda a matéria, abelhas e poetas.

(BRANDÃO, 2006, p. 547)

Essas tantas, diversas, mas as mesmas dálias não se permitem ver de relance. Olham de volta, apelam ao olhar da poeta, oferecem-se à sua colheita, vão alimentá-la, como às abelhas, que do néctar das flores podem criar outra coisa. O mel, a cera - o poema. Trata-se aqui de outra metamorfose, porém. Esse coração que as flores vão ornamentar e nutrir será para elas "sepultura". A delas mesmas, mortas, ou a de alguém cujo túmulo virão assinalar? De um modo ou de outro, a natureza-morta passa a ser concebida como uma cena de morte. Confusão de sentidos aqui sugerida que se concretiza em dois poemas que de fato referem a expressão.5 O primeiro, já no título: "Natureza morta com louvadeus":

Foi o último hóspede a sentar-se no topo da mesa, já depois do martírio.

As asas magníficas haviam-lhe sido quebradas por algum vento. Perdera o rumo sobre a película cintilante de água no riacho parado. Tal como poisou junto de nós, com o belo corpo magro arquejante, lembrava, ainda segundo o seu nome, um santo mártir. Enquanto meditávamos, a morte sobreveio, e a pequena criatura, que viera partilhar a nossa mesa, depois de ter sido banida das águas foi banida da terra. Alguém pegou no volúvel alado corpo morto abandonado sem nexo na brancura da toalha - que maculava e o atirou para qualquer arbusto raro

5 Neste caso e em outras ocorrências da expressão em seus poemas, Fiama opta pela omissão do hífen (gramaticalmente previsto), o que certamente contribui para a virtuosa confusão de sentidos a que nos referimos, abrindo à deriva de significações um termo de outro modo cristalizado. 
que o poeta ainda pôde fotografar.

(BRANDÃO, 2006, p. 487)

Ao contrário dos insetos que povoam a tela de Balthasar van der Ast, como muitas outras, este louvadeus está morto. É a sua morte, narrada, que vai dar nome ao poema, torná-lo uma natureza-morta. É sutil o truque de Fiama. Consiste em insinuar uma leitura literal da expressão, criando uma ambiguidade, um equívoco, propondo um sentido outro, que virá se sobrepor ou, ao menos, incidir sobre o primeiro. Natureza-morta: a morte da natureza, o lugar onde a natureza vem morrer, o resultado dessa morte, o seu testemunho, o seu monumento - fúnebre.

O intertexto religioso do poema acentua o sentido de uma morte a princípio banal. Sacraliza o fim de um inseto, mas não de um inseto qualquer - um louvadeus, que "lembrava, ainda segundo seu nome, / um santo mártir", e veio partilhar a mesa de alguma ceia, em que acabará por ser o sacrifício oferecido. O seu "volúvel alado corpo morto / abandonado sem nexo na brancura da toalha / - que maculava -" se imprime também na página do poema (vertida em sudário6), que se torna repositório, relicário, elegia, fotografia. Sepultura, como aquela que devora as dálias.

No poema 11 de Área branca, "Poderei divagar entre coisas alienadas", estabelece-se desde o princípio um modo de composição próprio da natureza-morta como gênero pictórico, para, então, instaurar-se mais uma vez a sua leitura equívoca.

Poderei divagar entre coisas alienadas
desde que não me coloque
no centro da semi-esfera do mar
no horizonte, como os poetas
de há um século. Poderei não ser
a referência de um ponto, à distância
do qual o rebanho de ovelhas
levadas a parir na primavera
misteriosa ficou desconhecido
e inesquecível. Ou o ponto para avaliar
a realidade de um tanque de sangue negro
onde peixes mortos brancos flutuavam
como se fossem formas planas.
Havia na morte uma palidez familiar,
o constante baloiçar benigno
da água doméstica, sem marés.
Jorravam da bica da catarata
peixes atirados para as regueiras;
adejavam, na podridão, libélulas
de metal azul na sua aparência,
mas frágeis e, ao cair na água,

6 Esta analogia me foi apontada pelo colega Paulo Ricardo Braz de Souza, quando apresentei uma prévia deste texto na UFF, em maio de 2018.

Diadorim, Rio de Janeiro, vol. 20, n. 1, p, 22-36, jan-jun. 2018. 
semelhantes a outros seres mortos.

Tudo estava como um quadro de natureza-

-morta, com árvores, na sua clemência

deixando as mãos colhê-las.

Era um pomar e um aviário em repouso,

cheios de formas sem sentimentos

que obedeciam apenas ao capricho

da sua duração.

Ao crepúsculo.

os rígidos emissários da noite,

vagalumes, assentavam os seus anéis

sobre a face da terra luminosa.

Mas nenhum conceito lírico

separava os objectos alados

dos outros objetos inertes da matéria.

Como se um drapeado de cetim

e uma fruteira clássica sobre ele

fossem representados nas árvores altivas

com uma colheita fecunda.

Como se a copa se arqueasse

num vão de níquel no esconso

de uma cristaleira baça

e derramasse bagos e pomos

rosados. E por detrás da composição

as flores que atapetavam

o terreno em tufos pareciam

desfolhar-se deixando suspensas

as pétalas, formas voláteis e mortas

no fundo a óleo. A insistência

em imagens antigas, paisagens

enrugadas como estampas,

não me faz sentir de súbito

inspirada e possuidora.

Antes me desprendo do tempo

e me afasto no poema

das metáforas, ou seja,

deixo-me encandear pela luz

das visões, sentindo que a memória

é superficial e retém a face

plena e visionária das coisas

na sua autonomia sublime.

(BRANDÃO, 2006, p. 291-2)

O pensar por meio das coisas, proposta mais uma vez anunciada no primeiro verso desta composição, se confirma pela renúncia do eu a ocupar o ponto de referência, o centro a partir do qual o real se enquadra, se mensura e organiza, e se determinam a importância e o sentido de todos os elementos. Refletindo não só sobre as naturezas-mortas, mas sobre a pintura holandesa 
do século XVII em geral, Svetlana Alpers aponta essa abdicação como traço fundamental de uma escola que privilegia a descrição do mundo visto em detrimento da imitação de ações humanas: "Uma série de características das imagens parece depender disso: a frequente ausência de um observador posicionado, como se o mundo viesse primeiro" (ALPERS, 1984, p. XXV. Tradução minha). O centro já não cabe ao homem, já não é ele a medida de todas as coisas - são elas que têm a primazia. Assim, como num quadro cuja escala não respeita a perspectiva linear, o rebanho de ovelhas na distância é justaposto a um tanque de peixes mortos. Mas aí vai mais do que uma crise de escala. A associação de motivos holandeses (o quadro pastoril com o rebanho e o tanque de peixes) cede espaço a um cenário em que confluem a representação de objetos inanimados e a cena da morte de seres (até então) vivos.

A imagem abjeta do tanque de peixes mortos, mergulhados em sangue, cercados por libélulas que caem na água "semelhantes a outros seres mortos" tem uma violência que não condiz com a serenidade estática das telas de natureza-morta. E, no entanto, herda dessa referência que parodia o tratamento estetizante das coisas: o contraste em chiaroscuro dos peixes brancos mergulhados em sangue negro, seus corpos que flutuam "como se fossem formas planas", a consciência de superfície - de tela - embutida nesta visão. A morte assume "uma palidez familiar", é domesticada, e a cena terrível é resumida assim: "Tudo estava como um quadro de natureza- / -morta". O "como" respeita o intervalo irônico de uma analogia questionável, imperfeita, bem como faz o enjambement, que hesita ao transformar a situação de morte da natureza numa pintura de natureza-morta. O hífen sela, porém, a confusão dos dois sentidos, chave de leitura do poema.

A paisagem externa do jardim e o interior doméstico vão-se imiscuindo, cristalizando o movimento próprio de uma "cena viva" na inércia de uma natureza-morta. Esta "natureza-morta" tem árvores, é um pomar, um aviário, mas "em repouso / cheios de formas sem sentimentos" - observação que soa como um outro modo de dizer representação de objetos inanimados. Vaga-lumes, ainda em voo, vêm iluminar a cena, "Mas nenhum conceito lírico / separava os objetos alados / dos outros objetos inertes da matéria." - neste último verso, mais um modo de parafrasear a definição do gênero pictórico. No espaço do poema, na sua concepção lírica, nada separa, tudo faz fundirem-se, confundirem-se, os planos: vivos e mortos, ágeis e inertes, animados e inanimados, seres e representações. Ao crepúsculo, que prenuncia um lusco-fusco típico das telas, toda a paisagem do quintal se vai convertendo em objetos de uma cena interior, elementos tradicionais de pintura, até serem pintura mesmo. Uma natureza-morta que se vai vislumbrando no poema conforme a paisagem vai-se metamorfoseando, num apocalipse da natureza: as árvores altivas representam uma fruteira sobre um drapeado de cetim, e logo arqueiam suas copas, derramando bagos e pomos, como se tombassem; as flores já caídas se despetalam e as pétalas são "formas voláteis e mortas / no fundo a óleo". Aventando a questão: representar será, então, fazer morrer? Ou: testemunhar a morte? Ou mesmo: morrer?

É o que parece sugerir este poema em sua progressão. De início, o eu se despoja de seu lu- 
gar privilegiado, instaurando um modo de estar em deslocamento, que põe em questão a certeza humanista e suicida o sujeito egocêntrico romântico ("desde que não me coloque / no centro [...] como os poetas / de há um século"). Assumir essa condição significa não mais "avaliar / a realidade", como uma razão dominante, mas apenas dá-la a ver: um trabalho do olhar que não resulta em ganho, mas em perda: "A insistência / em imagens antigas, paisagens / enrugadas como estampas, / não me faz sentir de súbito / inspirada e possuidora.”. Mais um desapossamento. As coisas, cada vez mais coisas, tomam precedência, até que todo o mundo seja coisa apenas: a natureza - um quadro; paisagens - estampas. Assim destituído, o eu continua sua deriva: “[...] me desprendo do tempo / e me afasto no poema”. Não do poema, mas no poema, espaço de dispersão, de desaparecimento.

Mas o verso continua: "e me afasto no poema / das metáforas, [...]": o que poderia sugerir um desfazer do trabalho poético que levara até este ponto, uma desconstrução do regime metafórico que associava paisagem natural e natureza-morta, real e representação, acaba por reafirmar o movimento inicial. Afastar-se das metáforas será mais um modo de dar primazia absoluta às coisas, desautorizando um eu-poeta que ainda intervinha ativamente sobre elas, pondo-as em relação. "e me afasto no poema / das metáforas, ou seja, / deixo-me encandear pela luz / das visões [...]". "Encandear" significa ofuscar ou deslumbrar; cegar por excesso de luz. A primeira acepção do verbo remete mesmo à caça e à pesca, referindo o uso do candeio (feixe de luz) para desorientar e capturar animais. E tornamos assim, com este eu/poeta que se sacrifica e se deixa encandear pela luz - ofuscado e apanhado para a morte - ao tanque de peixes: imagem obsedante do poema, que o desencadeia e que retorna ao final, renomeada: "memória" - o que resta deste sujeito e do mundo, numa presença em ausência, numa representação.

Como o tanque onde os peixes mortos flutuavam "como se fossem formas planas"; como as naturezas-mortas menos janelas do que mapas ou espelhos, a memória "é superficial e retém a face / plena e visionária das coisas / na sua autonomia sublime." Imagem do poema em si: natureza-morta; sepultura de peixes, de dálias, de um louvadeus, a lembrar um incômodo no verso final: "que o poeta ainda pôde fotografar." - garantia de que algo do louvadeus (mesmo que cadáver) se salva? ou urgência do poeta, seu ato último, à pressa, nesta cena em que "a morte sobreveio"? A lembrar, sobretudo, outros versos de Fiama: “[...] os poetas todos / morrem sempre mais na língua.” (BRANDÃO, 2006, p. 621), como que ecoando um alerta de Blanchot: "quem mergulha no verso morre, encontra a sua morte como abismo" (BLANCHOT, 2013, p. 31. Tradução modificada).

Talvez pudéssemos dizer que os pintores de naturezas-mortas morrem sempre mais na imagem. Com raras exceções, a figura humana é elidida dessas composições dominadas por objetos. Mas algumas telas inscrevem a presença de um sujeito como vestígio. Clara Peeters, pintora holandesa do século XVII, fez-se autorretratar em uma de suas obras (fig. 4): 
FIGURA 4. Clara Peeters. "Natureza-morta com flores". / Detalhe. Óleo sobre tela, 1611.

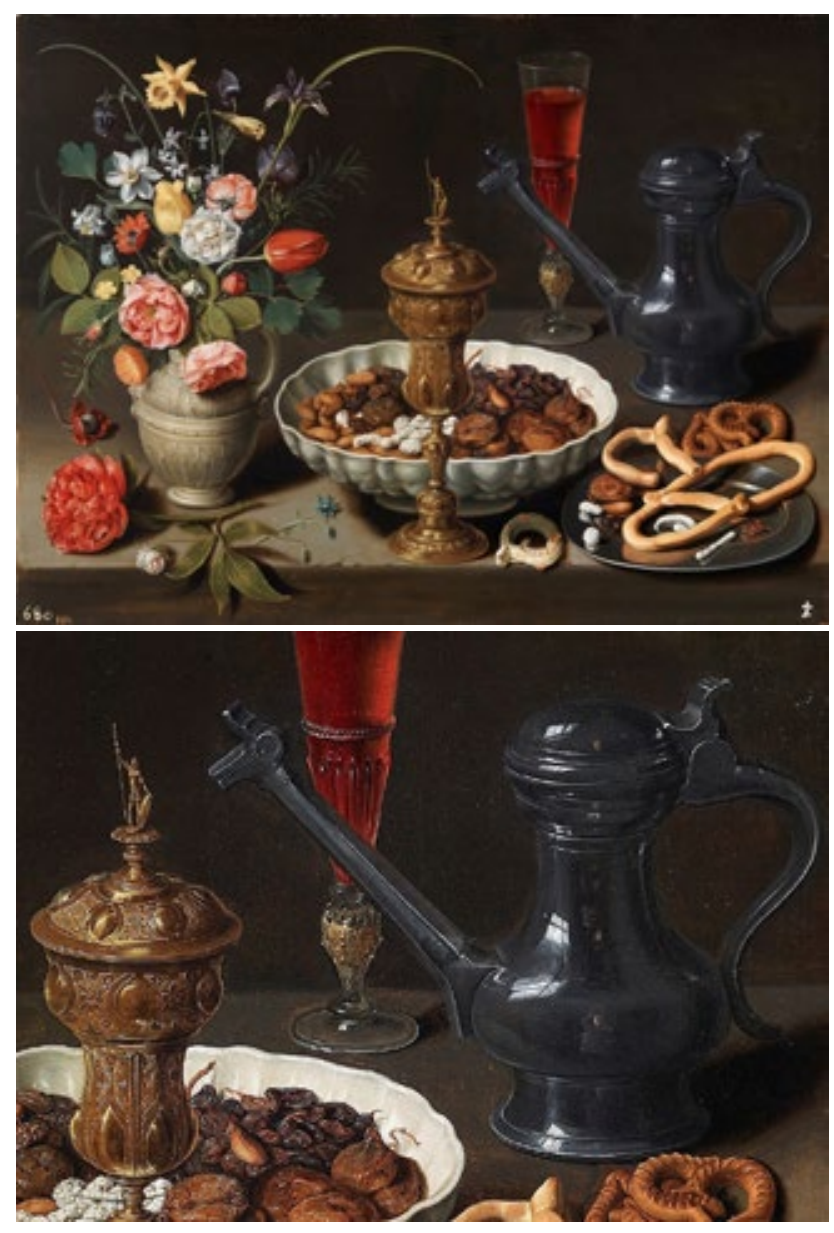

Uma série de imagens da pintora aparecem espelhadas no bule de estanho, como se ela estivesse diante da cena e se tivesse deixado capturar na sua representação. Efeito mimético com consequências imprevisíveis: vítima da luz, como Fiama, que se deixa encandear, Clara se deixa refletir a contraluz, e vai-se fundir aos objetos inanimados, eternamente presa no ato de observá-los. Inscreve-se neles como o que Mark Doty chama uma "qualidade da atenção", "que voa para fora, que nos liga ao mundo" (DOTY, 2001, p. 49-50. Tradução minha).

Um modo de descentramento do sujeito, de conexão com o mundo que Fiama vai reconhecer, a um só tempo, como fatalidade e como salvação, nos versos de um poema cujo título une o verbal e o visual: "Poesia nítida".

Só em mim a atenção é um modo de doer, e o que hoje dói flui como um bálsamo. (BRANDÃO, 2006, p. 526)

Para Mark Doty, a atenção será chave de uma prodigiosa metamorfose:

the eye suffuses what it sees with the I. Not "I" in the sense of my story, the particulars of my life [...], but "I" as the quickest, subtlest thing we are: a moment of attention, an intimate engagement. [...] ultimately I becomes an eye 
O olho preenche o que vê com o eu. Não "eu" no sentido da minha história, dos detalhes da minha vida, mas "eu" como a coisa mais ligeira, mais sutil que somos: um momento de atenção, um compromisso íntimo. Por fim um eu se torna um olho (Tradução minha, grifos meus.)7

É um modo de morrer, sem dúvida, mas também um modo de permanecer. "Onde havia uma vida agora há uma forma", sentencia Mark Doty (2001, p. 50. Tradução minha). O bule de estanho onde se estampam os autorretratos de Clara Peeters está impregnado desse olhar que o viu. Não é um objeto qualquer, mas um objeto visto por alguém; e nos olha de volta (retorna o verso: "que o poeta ainda pôde fotografar" - objeto e olhar capturados pela luz). Torna-se um repositório dessa subjetividade que nele subsiste, desse olhar que nele repousa. Facilmente cairíamos na tentação de lê-lo como alegoria da memória segundo Fiama: "superficial”, capaz de "rete[r] a face plena e visionária das coisas".

Talvez possamos finalmente entender a virtude de se dedicar ao aprendizado de ver as naturezas-mortas, de compreender que o mundo é figura delas, de treinar o olhar para apreender todo o real como se fosse uma natureza-morta. Para além da renúncia e do sacrifício que implica (ou por causa disso), essa educação inventa ou descobre um modo de convívio com as coisas, um modo de estar no tempo, de permanecer, de ser histórico para além de uma vida e de um corpo limitados. Ou: ensina a escrever.

Modo histórico da cidra

Numa lápide, afinal, num puro tampo

(de mesa), um ente nasce:

o fruto (diáfano); cidra, em si a sua origem;

vem do tempo, celta ou da ibéria, já

me transcende? Ó reino pressuposto de um

vegetal; essa paragem - cidra - no percurso.

Num tempo celebrado, o aniversário.

É um suco mortífero, ou o de um real

aberto porque o vêem muitos modos ou o dizem.

Meus anos expostos (a frutos) que formas

confirmaram; ou, mais longínquo,

houve o soalho; no espaço, a hora ocorre.

A omissão de cidra ou mármore ágrio é um dom

do luto: meu exercício e o mundo.

E que urna ou ornamento (essa mesa)? É

um sentido vário; não que pereça,

mas, quando imóvel, muda. A emoção de ser

corpo (um fruto) decomposto que hoje

7 A reprodução do original se faz necessária para preservar o jogo de sentido que depende da coincidência sonora entre "I" (eu) e "eye" (olho), em inglês.

Diadorim, Rio de Janeiro, vol. 20, n. 1, p, 22-36, jan-jun. 2018. 
recrio ou lego: a minha existência

(entre os iberos) urge.

(BRANDÃO, 2006, p. 144)

A mesa onde repousa a cidra; a cidra mesma, que aí se inscreve, é lugar de morte (lápide) e de nascimento (versão). O fruto contém em si a própria origem, o pretérito e o futuro; é, num dia de aniversário - mais um ano de vida, menos um ano de vida -, uma forma de morrer ("suco mortífero") e uma forma de sobrevivência ("real / aberto porque o veem muitos modos ou o dizem"). A poeta vê a cidra, com atenção: "essa paragem - cidra - no percurso", e se vai convertendo em cidra - "A emoção de ser corpo (um fruto) decomposto", em inércia, em falta. A palavra "omissão" faz confluírem esses dois sentidos: insistência em permanecer, estando ausente. Antinomia que se resume como "um dom / do luto". Este exercício que a poeta assume como seu ("meu exercício") é um trabalho de linguagem, que Blanchot concebe precisamente assim, como um trabalho de luto: "vida que carrega a morte e nela se mantém" (BLANCHOT, 1997, p. 323). Investida desse dom, a própria cidra se transfigura em mármore (que vai conservar a qualidade do azedo "ágrio" da fruta), em urna, em ornamento (fúnebre) e afinal em mesa - pouso da escrita. Explicam-se as metamorfoses: "É um sentido vário; não que pereça, mas, quando imóvel, muda.”. E chegamos à conclusão de que essa leitura ficaria muito mais simples se puséssemos uma errata: onde se lê "cidra", leia-se "poema", ou "literatura".

É o texto "o corpo (um fruto) decomposto" que Fiama recria e deixa como legado, segundo aquele progresso a que chamou "epigráfico. Lápide e versão, indistintamente" (BRANDÃO, 2006, p. 173). Inclui-se assim a si mesma, enquanto texto, nessa cadeia de morte e renascimento, demarcando o seu lugar de permanência: existência que urge - frágil, mas impositiva, como um objeto de natureza-morta, impregnado de um olhar amoroso, capturado sob a luz:

[...] Olho os versos que me habituei a manejar um a um.

Este é um manuscrito. Poisa-se na escrivaninha, liso debaixo do lustre que escorre luz impetuosamente. [...]

(BRANDÃO, 2006, p. 526)

\section{Referências}

ALPERS, Svetlana. The Art of describing. Dutch art in the seventeenth century. Chicago: The Chicago University Press, 1984.

BLANCHOT, Maurice. A Literatura e o direito à morte. In: ---. A Parte do fogo. Trad. Ana Maria Scherer. Rio de Janeiro: Rocco, 1997.

O Espaço Literário. Trad. Álvaro Cabral. Rio de Janeiro: Rocco, 2013.

Diadorim, Rio de Janeiro, vol. 20, n. 1, p, 22-36, jan-jun. 2018. 
BRANDÃO, Fiama Hasse Pais. Obra Breve. Poesia reunida. Lisboa: Assírio \& Alvim, 2006.

BRYSON, Norman. Looking at the overlooked. Four essays on still life painting. London: Reaktion Books, 2012.

CHERRY, Peter. In the presence of things. Two centuries of still life painting. In: In the Presence of Things: Four Centuries of European Still-life Painting. Vol. 1. Catálogo de Exposição. Lisboa: Fundação Calouste Gulbenkian, 2010. p. 12-67.

DOTY, Mark. Still life with oysters and lemon. Boston: Beacon Press, 2001.

e KING, Andrew David. The Lessons of objects: an interview with Mark Doty. Disponível em: http://www.kenyonreview.org/2012/12/mark-doty-interview. Consultado em janeiro de 2013.

SILVEIRA, Jorge Fernandes da. Lápide \& versão: ensaios sobre Fiama Hasse Pais Brandão seguidos de Memorial da Pedra - Antologia poética. Rio de Janeiro: Bruxedo, 2006. 